\title{
A "Wild Day Out!": finding wildlife in the Glasgow Botanic Gardens
}

\author{
S.J. Forster \\ RSPB South West Scotland Regional Office, 10 Park Quadrant, Glasgow G3 6BS \\ E-mail: sarah-jayne.forster@rspb.org.uk
}

\begin{abstract}
The Royal Society for the Protection of Birds (RSPB) held "Wild Day Out!" in the Glasgow Botanic Gardens (GBG) on 2nd September 2017. The objectives of the event were: knowing more about wildlife, recording wildlife, public engagement with nature, and partnerships. Included in a range of activities was a Bioblitz during which 71 new species records for the GBG were obtained. Of particular interest were the landhopper Arcitalitrus dorrieni (second record for Glasgow) and the bulrush wainscot moth (Nonagria typhae) (first adult record for Glasgow).
\end{abstract}

\section{INTRODUCTION}

For the launch event of RSPB's Glasgow WildFest (2017), and as a contribution to the bicentenary of the GBG, RSPB held "Wild Day Out!" in the GBG on the 2nd September 2017. This event included a Bioblitz, a large-scale recording event aimed at taking a snapshot of all the species present at a site at a given time. This was the largest scale survey event for 20 years, when there was a similar snapshot taken in 1997 with a project called "Glasgow Botanic Gardens: On The Wildside" (Hancock, 1997, 1998).

\section{Objectives of the Bioblitz}

Knowing more about wildlife!

It is important to know the species that live in the GBG to see how management affects species and how these change over time. For the RSPB, this is especially important for urban priority species: bats (Microchiroptera), house sparrows (Passer domesticus), common swifts (Apus apus) and bumblebees (Bombus spp.). We can use this information to engage with people in the GBG about their local environment and talk about a range of different species. Over the last few years RSPB have been working with the GBG to think about the species that live there and engaging people with them, from doing mini-beast education session with schools to membership recruiters engaging with other visitors. As part of WildFest, RSPB Scotland created the "Beast of the Botanics" trail to engage children with the species that live there, and to encourage them to look for animals from amphibians to insects as part of their visit.

\section{Records}

It is vitally important to record species over time to detect trends so that action can be taken to improve species diversity through conservation work. In the first State of Nature Report (Burns et al., 2013), several wildlife organisations collaborated to present how British wildlife was faring. The State of Nature Report presented a very positive outlook on the importance of voluntary biological recording, stating that the "contribution of voluntary and amateur recording to our understanding of UK wildlife populations and distributions is now world leading and its significance vitally important to national monitoring and conservation efforts".

\section{Public engagement with nature}

In Scotland there is an increasingly urbanised population and a rising disconnection with nature. The major objective of RSPB's Giving Nature a Home project is to reconnect the people of Glasgow with nature, since exposure to natural spaces - everything from parks and open countryside to gardens and other greenspace - is beneficial for health (Muñoz, 2009). A Bioblitz is a great way to showcase the amount of wildlife that exists in green spaces in an exciting way that allows the general public to carry out scientific surveys and talk to a wide range of experts about wildlife and conservation. Doing such events in urban areas makes them more accessible to people that would not necessarily visit reserves or go out of their way to access nature. Such an event can therefore act as a first step in connecting disconnected groups. Removing transport costs also makes such events more accessible to those from disadvantaged backgrounds. The 2017 WildFest was the fourth in successive years and aimed to get more people engaged with wildlife on their doorstep. The festival attracted 6,210 people directly through citizen science walks and talks, and green space events. Working with over 40 community groups, it delivered a month-long wildlife festival across the city generating increased opportunities for children to connect with nature and a better understanding of what wildlife is present in local green spaces.

\section{Partnerships}

The Glasgow Giving Nature a Home project started in April 2014 with the mission of connecting children, families and community groups to create a city-wide wildlife garden, and celebrating nature within Glasgow. Since then the project has engaged with many individuals, families, schools and communities as well as partnering with a number of organisations to make the city better for nature. The project completes work year round with schools through outreach work, Ambassador Schools and community conservation work. 


\section{"Wild Day Out!" activities}

The day included a range of activities in addition to the Bioblitz:

- Children's activities such as bug-hunting, pond-dipping, face-painting, storytelling and gardening run by RSPB in the GBG, and by Children's Wood volunteers in North Kelvin meadow.

- The "Conservation Village" (Fig. 1) comprised stalls staffed by many conservation and wildlife organisations: RSPB, Butterfly Conservation, Marine Conservation Scotland, Glasgow City Council Countryside Rangers, The Conservation Volunteers, Saving Our Red Squirrels, Scottish Badgers, Grow Wild,

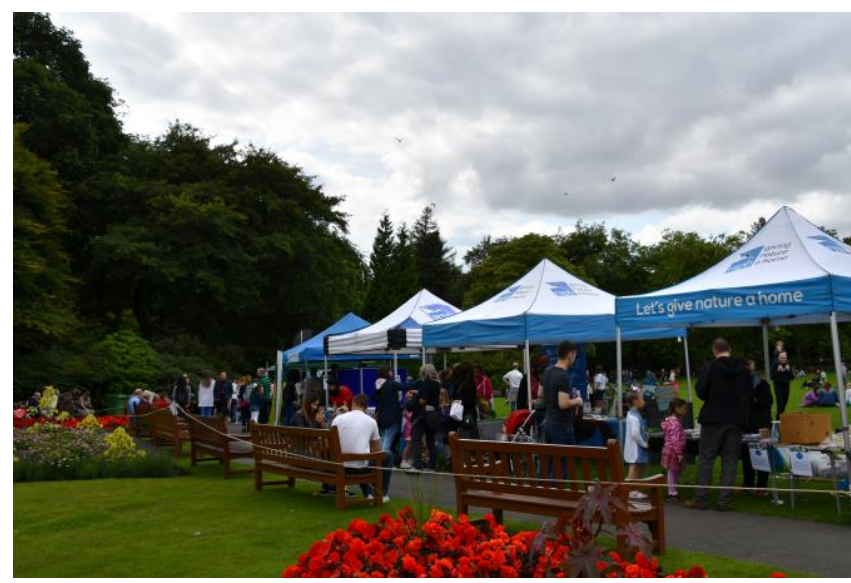

Fig. 1. The "Conservation Village", with stalls staffed by conservation and wildlife organisations in the Glasgow Botanic Gardens. (Photo credit: G. Vaux)

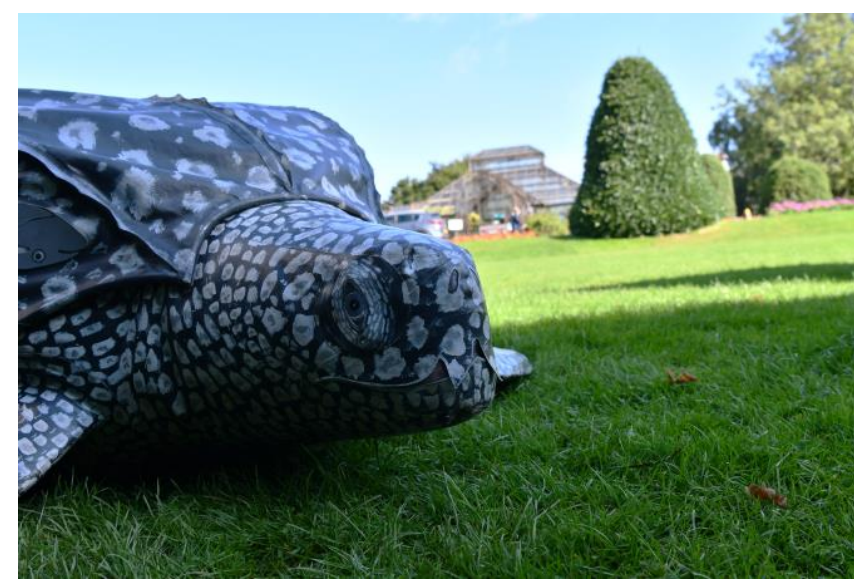

Fig. 3. A leatherback turtle (Dermochelys coriacea) in the Glasgow Botanic Gardens! (Photo credit: G. Vaux)
Glasgow Natural History Society, Friends of Glasgow Botanic Gardens.

- "Species Identification Laboratory" (Fig. 2) inside the Kibble Palace, staffed by Glasgow Museums experts.

- Guided walks and workshops including: early morning birds, bird ringing, botanical recording, marine turtle conservation (Fig. 3), lichens, small mammals, moths, pollinators, the history of the River Kelvin, bugs, filmy ferns, and "worm-charming" - a competition between families to attract the most earthworms (Annelida) by stamping on the ground for 30 minutes (Fig. 4).

The number of people participating in events over the day totalled over 1,800 adults and 1,500 children.

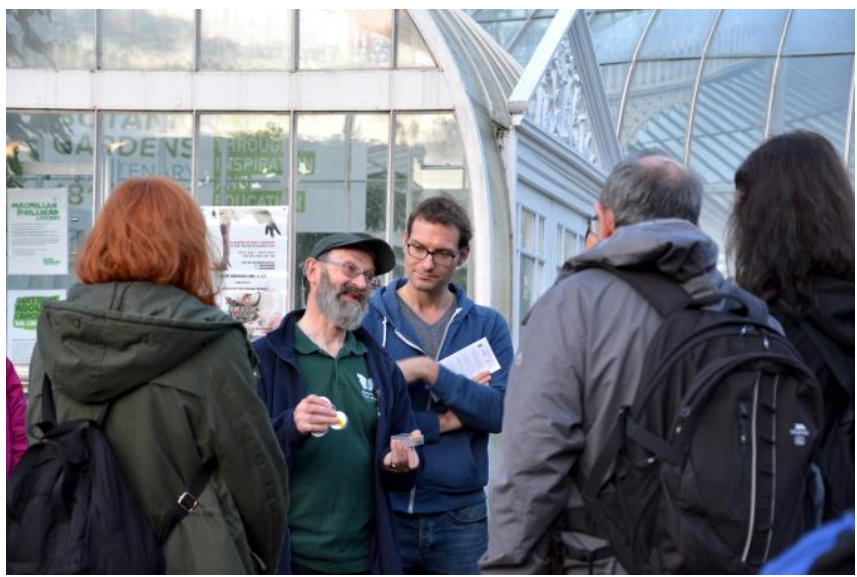

Fig. 2. The "Species Identification Laboratory", staffed by Glasgow Museums experts in the Kibble Palace, Glasgow Botanic Gardens. (Photo credit: G. Vaux)

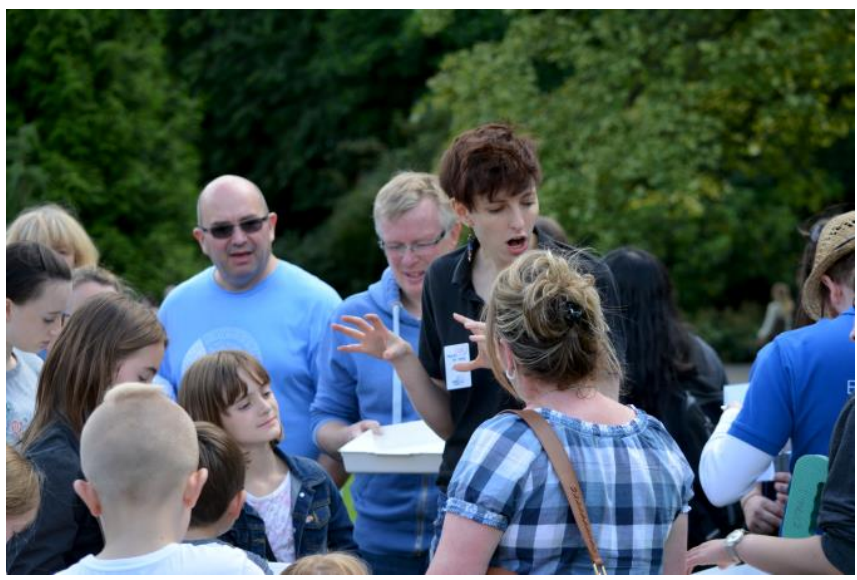

Fig. 4. Explaining "worm-charming", a competition between families to attract the most earthworms (Annelida) by stamping on the ground for 30 minutes. (Photo credit: G. Vaux) 


\section{Accuracy of information and verification during the Bioblitz}

The methodologies followed best practice and standard techniques when and where possible. A range of ponddipping and invertebrate nets, bat detectors, GPS survey equipment, field identification sheets and field guides were used.

Bats were recorded using hand-held acoustic bat detectors, which recorded the presence of bats using echo-sound, and specialists identified the sounds to species level.

Longworth small mammal traps were used to trap mammals. These were baited with appropriate food (mealworms, hamster food and fresh fruit) and bedding (hay). They were set up at dusk on the previous evening and checked again the following morning. Invertebrates were caught using sweep nets and jars, and specialist light traps were used for moths. Specimens were taken only where analysis after the event was necessary for verification of species. The recording sheets used to note species were thought to be clear and were successful at recording information.

\section{RESULTS}

From the "Wild Day Out!" Bioblitz many species known to be present were found in GBG such as a newt (Lissotriton sp.), a common frog (Rana temporaria), grey squirrels (Sciurus carolinensis) and a mouse (Mus sp.). More interestingly 71 new species records were obtained for the GBG (Table 1). These included some common but not previously recorded species such as the grey worm (Aporrectodea caliginosa), but also some more unusual species for the time of year, such as the whooper swan (Cygnus cygnus). The latter was a surprise, though we learnt later that there are two individuals known to be resident on the River Kelvin.

The most notable species of the day was the crustacean landhopper Arcitalitrus dorrieni, only the second record for Glasgow; the few other Scottish records seem to be exclusively from the islands or western coastal areas (R. Weddle, pers. comm.).

There were also some interesting moths found including the bulrush wainscot (Nonagria typhae), the first adult record from within Glasgow, though it has been seen in recent years in Bishopbriggs and the Motherwell area (R. Weddle, pers. comm.).

\section{ACKNOWLEDGEMENTS}

I thank: Gregory Vaux, RSPB, for permission to use the photographs; Roger Downie and Richard Weddle for comments on the manuscript; and Glasgow Museums Biological Records Centre and other expert volunteers for species verifications.

\begin{tabular}{ll}
\hline Group & N \\
\hline Fern (Polypodiopsida) & 3 \\
Flowering plant (angiosperms) & 41 \\
Worm (Annelida) & 2 \\
Mollusc (Mollusca) & 1 \\
Crustacean (Crustacea) & 1 \\
Harvestman (Opiliones) & 1 \\
Insect - alderfly (Sialidae) & 1 \\
Insect - beetle (Coleoptera) & 2 \\
Insect - bee/wasps (Hymenoptera) & 5 \\
Insect - moth (Lepidoptera) & 1 \\
Insect - true bug (Hemiptera) & 4 \\
Insect - true fly (Diptera) & 6 \\
Spider (Araneae) & 1 \\
Springtail (Collembola) & 1 \\
Bird (Aves) & 1 \\
\hline
\end{tabular}

Table 1. New species records in the Glasgow Botanic Gardens, 2nd September 2017, noted during the "Wild Day Out!", by species group. $\mathrm{N}=$ number of new species.

\section{REFERENCES}

Hancock, E.G. (Editor). (1998). On the Wildside: the natural history of the Glasgow Botanic Gardens. The Glasgow Naturalist 23(3), 40-56.

Hancock, E.G. (Editor). (1999). On the Wildside: the natural history of the Glasgow Botanic Gardens. The Glasgow Naturalist 23(4), 59-64.

Burns, F., Eaton, M.A., Gregory, R.D., Al Fulaij, N., August, T.A., Biggs, J., Bladwell, S., Brereton, T., Brooks, D.R., Clubbe, C., Dawson, J., Dunn, E., Edwards, B., Falk, S.J., Gent, T., Gibbons, D.W., Gurney, M., Haysom, K.A., Henshaw, S., Hodgetts, N.G., Isaac, N.J.B., McLaughlin, M., Musgrove, A.J., Noble, D.G., O’Mahony, E., Pacheco, M., Roy, D.B., Sears. J., Shardlow, M., Stringer, C., Taylor, A., Thompson, P., Walker, K.J., Walton, P., Willing, M.J., Wilson, J. \& Wynde, R. (2013). State of Nature Report. The State of Nature partnership. http://ww2.rspb.org.uk/Images/stateofnature_tcm9345839.pdf

Muñoz, S-A. (2009). Children in the Outdoors: A Literature Review. Sustainable Development Research Centre, Forres, Morayshire. 